ORIENTAL JOURNAL OF CHEMISTRY

An International Open Free Access, Peer Reviewed Research Journal

www.orientjchem.org
ISSN: 0970-020 X

CODEN: OJCHEG

2018, Vol. 34, No.(1):

Pg. 573- 575

(Brief Communication)

\title{
Antibacterial Activity of Extract from Swamp Plant, Eleocharis dulcis
}

\author{
ACE BAEHAKI, HERPANDI and AAN ANDRI PUTRA \\ Department of Fisheries Product Technology, Faculty of Agriculture, Sriwijaya University, \\ Indralaya, South Sumatera, Indonesia. \\ ${ }^{*}$ Corresponding author E-mail: ace76_none@yahoo.com \\ http://dx.doi.org/10.13005/ojc/340168
}

(Received: November 21, 2017; Accepted: December 10, 2017)

\section{ABSTRACT}

The purpose of the research was to access bacterial activity from swamp plant extract of Eleocharis dulcis against Bacillus subilis, Pseudomonas aeruginosa and Vibrio cholera. The phytochemical compounds of ethanol extract of Eleocharis dulcis were tannins, flavonoids and triterpenoids. Phytochemical compounds of ethyl acetate and $n$-hexane extracts were flavonoids and triterpenoids. The maximum antibacterial activity the all of solvents in $2.000 \mathrm{ppm}$ concentration. The bacterial activity of Eleocharis dulcis extract against Bacillus subtilis higher than that of Pseudomonas aeruginosa and Vibrio cholera.

Keywords: Swamp plant, Eleocharis dulcis, antibacterial

\section{INTRODUCTION}

Research on various types of plants, both marine plants and freshwater plants has been conducted to assess the potential of bioactive components that are useful as antioxidants and antibacterials. Each plant contains several types of bioactive substances which are natural chemicals contained in the plant and can be a member of the taste, aroma and color of the plant'. Phytochemical compounds in plants also serve to protect themselves from environmental factors that cause damage such as free radicals and pathogenic bacteria ${ }^{2}$.

Some Plant produce antibacterial compounds that inhibits or killed many bacteria and there are many reports describing antioxidant activities $^{3-5}$, anti-inflammatory ${ }^{6}$, and antidiabetic ${ }^{7}$. However reports on the phytochemical constituents of swamp plant and their bioactive activity of swamp plant are limited, we reported that antibacterial activity of extracts of Purun Tikus (Eleocharis dulcis) used $n$-hexane, ethyl acetate and etanol as solvents. 


\section{MATERIALS AND METHODS}

\section{Preparation of Eleocharis dulcis}

Leaves of Eleocharis dulcis were collected from Indralaya swamp and immediately brought to the laboratory in sterile plastic bags containing water to prevent evaporation. Leaves of Eleocharis dulcis were washed thoroughly with distilled water to remove extraneous materials and shade-dried for 10 days at room temperature until constant weight obtained. The dried Leaves of Eleocharis dulcis were powdered and stored in refrigerator for future use.

\section{Extraction of Eleocharis dulcis}

Extraction of Eleocharis dulcis by stratified maceration method using $n$-hexane, ethyl acetate and ethanol.

\section{Phytochemical Screening of Eleocharis dulcis extract}

Phytochemical Screening of alkaloids, flavonoids, triterpenoids steroids, saponin, were determined by Harborne method ${ }^{8}$.

\section{Antibacterial test}

Pathogens bacterial (Pseudomonas aeruginosa, Bacillus subtilis and Vibrio cholera) used in this study. Antibacterial activity was evaluated using diffusion method ${ }^{9}$.

\section{RESULT AND DISCUSSION}

Screening of phytochemical from extract of Eleocharis dulcis

Screening of phytochemical from extract of Eleocharis dulcis can be seen Table.1.
The result showed content of phytochemical compounds of ethanol extract of Eleocharis dulcis were tannins, flavonoids and triterpenoids. The phytochemical compounds of ethanol extract of Eleocharis dulcis were tannins, flavonoids and triterpenoids. Phytochemical compounds of ethyl acetate and n-hexane extracts were flavonoids and triterpenoids.

\section{Antibacterial activity}

Antibacterial activity from Eleocharis dulcis with different concentration of extract patogenic bacteria are depicted in Table. 2. The Antibacterial activity from Eleocharis dulcis againts Bacillus subilis, Pseudomonas aeruginosa and Vibrio cholera were peaked after $2.000 \mathrm{ppm}$ of extract concentration.

Table. 2 showed that the maximum antibacterial activity was recorded from the ethanol extracts of Eleocharis dulcis against Pseudomonas aeruginosa $(9 \mathrm{~mm})$, Bacillus subilis $(9.5 \mathrm{~mm})$ and Vibrio cholera $(10 \mathrm{~mm})$. The maximum antibacterial activity from the ethyl acetate extracts of Eleocharis dulcis against Pseudomonas aeruginosa $(9 \mathrm{~mm})$, Bacillus subilis $(10 \mathrm{~mm}$ ) and Vibrio cholera $(10.5 \mathrm{~mm})$. The maximum antibacterial activity from the $\mathrm{n}$-hexane extracts of Eleocharis dulcis against Pseudomonas aeruginosa $(10 \mathrm{~mm})$, Bacillus subilis $(12 \mathrm{~mm})$ and Vibrio cholera $(8.5 \mathrm{~mm})$. The bacterial activity of Eleocharis dulcis extract against Bacillus subtilis higher than that of Pseudomonas aeruginosa and Vibrio cholera.

Antimicrobial activity of Eleocharis dulcis extract may be primarily due to the presence of tannins and phenolic compound. Tannins have been traditionally used for treatment of catarrh, hemorrhoids and diarrhea ${ }^{10}$.

Table. 1: Screening of phytochemical from extracts of

Eleocharis dulcis

\begin{tabular}{lccc}
\hline Phytochemical & & Solvent & \\
& n-hexane & Ethyl acetate & Ethanol \\
\hline Alkaloid & - & - & - \\
Terpenoid & + & + & + \\
Tannin & - & - & + \\
Saponin & - & - & - \\
Flavonoid & + & + & + \\
\hline
\end{tabular}


Table. 2: Antibacterial activity of from extracts of Eleocharis dulcis

\begin{tabular}{|c|c|c|c|c|c|c|c|}
\hline \multirow[t]{2}{*}{ Pelarut } & \multirow[t]{2}{*}{ Bacteria } & \multicolumn{3}{|c|}{ Concentration (ppm) } & \multirow[b]{2}{*}{2000} & \multirow{2}{*}{$\begin{array}{l}\text { Control } \\
\text { Positive }\end{array}$} & \multirow{2}{*}{$\begin{array}{c}\text { Control } \\
\text { Negative }\end{array}$} \\
\hline & & 500 & 1000 & 1500 & & & \\
\hline \multirow[t]{3}{*}{ N-hexane } & Pseudomonas aruginosa & 7,5 & 8 & 9 & 10 & 31 & 6 \\
\hline & Bacillus subtilis & 9,5 & 9,5 & 10,5 & 12 & 30 & 6 \\
\hline & Vibrio cholera & 6,5 & 7 & 7.5 & 8,5 & 28 & 6,5 \\
\hline \multirow[t]{3}{*}{ Ethyl acetate } & Pseudomonas aruginosa & 7 & 7 & 8 & 9 & 30 & 6 \\
\hline & Bacillus subtilis & 9 & 9,5 & 11 & 10 & 31,5 & 6 \\
\hline & Vibrio cholera & 8,5 & 9,5 & 10 & 10,5 & 27,5 & 7 \\
\hline \multirow[t]{3}{*}{ Ethanol } & Pseudomonas aruginosa & 7 & 7,5 & 8 & 9 & 30,5 & 6 \\
\hline & Bacillus subtilis & 7 & 7,5 & 8,5 & 9,5 & 30 & 6,5 \\
\hline & Vibrio cholera & 7 & 8 & 9 & 10 & 26,5 & 7 \\
\hline
\end{tabular}

\section{CONCLUSION}

The phytochemical compounds of ethanol extract of Eleocharis dulcis were tannins, flavonoids and triterpenoids. The phytochemical compounds of ethanol extract of Eleocharis dulcis were tannins, flavonoids and triterpenoids. Phytochemical compounds of ethyl acetate and $n$-hexane extracts were flavonoids and triterpenoids. The bacterial activity of Eleocharis dulcis extract against Bacillus subtilis higher than that of Pseudomonas aeruginosa and Vibrio cholera.

\section{ACKNOWLEDGMENTS}

This research was support by Competitive Grant (Hibah Kompetensi 2017) from Ministry of Reseach, Technology and Higher Education (Kemenristekdikti), Republic of Indonesia.

\section{REFERENCES}

1. Winarsi H. Soy protein and sprouts are beneficial to health. Kanisius, Yogyakarta, 2010.

2. Salisbury FB, Ross CW. Plant Physiology, Fourth edition. Wadsworth Inc, Belmont, CA, 1992.

3. Baehaki A, Supriadi A, Pratama MC. Antioxidant activity of methanol extract of Halodule uninervis seagrass from the coastal of Lampung, Indonesia. Res. J. Pharma. Biol. Chem. Sci, 2016, 3, 1173-1177.

4 Baehaki, A, Lestari SD, Apriyanti W. Pytochemical screening and antioxidant activity of seeds extract of water plant (Nymphaea stellata and Nelumbo nucifera). J. Chem. Pharma. Res, 2015, 7(11), 221-224.

5. Baehaki A, Widastuti I, Herpandi, Jannah N. Antioxidant activity of extracts of Halodule pinifolia Seagrass from solvents with different polarities. Orient. J. Chem, 2017, 33(1), 181-185.

6. Kim B, Kim J E, Chio B, Kim H. Antiinflammatory effects of water chestnut extract on cytokine responses via nuclear factor-êBsignaling pathway, Biomol Ther, 2015, 23(1), 90-97.

7. Akah PA, Uzodinma SU and Okolo CE. Antidiabetic activity of aqueous and methanol extract and fractions of Gongronema latifolium (Asclepidaceae) leaves in alloxan diabetic rats. J. Applied Pharma. Sci. 2011, 1(9), 99-1-2.

8. Harborne JB. Phytochemical Methods 2nd edition. Chapman and Hall, New York, 1987.

9. Elgayyar M, Draughon FA, Golden DA, Mount JR. Antimicrobial activity of essential oils from plant against selected pathogenic and saprophytic microorganisms. J. Food Prot, 2001, 64(7), 1019-1024.

10. Senthilkumar M. Phytochemical screening of Glorisa superba L. -from different geographical positions. Inter. J. Sci. Res. Pub., 2013, 14. 